\title{
A Nexus of Group Learning and Collaborative Learning Facilities in Stimulating Oral Interaction of Learners: A Case of Saudi Arabia
}

\author{
Abdulbagi Babiker Ali Abulhassan ${ }^{1} \&$ Fatima Ibrahih Altayeb Hamid ${ }^{1}$ \\ ${ }^{1}$ Department of English, University College in Addair, Jazan University, Saudi Arabia \\ Correspondence: Abdulbagi Babiker Ali Abulhassan, Department of English, University College in Addair, Jazan \\ University, Saudi Arabia. E-mail: magaddam@yahoo.com
}

Received: March 2, 2021

doi:10.5539/ies.v14n7p101
Accepted: April 6, $2021 \quad$ Online Published: June 27, 2021

URL: https://doi.org/10.5539/ies.v14n7p101

\begin{abstract}
The collaborative learning environment promotes socialization and learning among the students. Therefore, the present study has focused on stimulating oral interaction among students through group and collaborative learning. A qualitative survey study was conducted by selecting ten tenth-grade male students with ages ranging between 14 and 15 years. A total of 10 students were randomly selected from collaborative learning classrooms and were asked about their experiences in that particular environment. The data gathered through interviews were transcribed and presented in the form of themes to highlight students' perceptions towards a collaborative learning environment. The results demonstrated that most students perceived that the collaborative learning environment was very beneficial for them. It built self-confidence, improved their oral presentation skills, made them responsible, performed diverse tasks, and respected opinions. Therefore, it is suggested that collaborative learning concepts should be implemented in EFL education programs for in-service and pre-service teachers.
\end{abstract}

Keywords: collaborative learning, group learning, learners, oral interaction

\section{Introduction}

Learning in groups plays a vital role in modern pedagogy, whether at kindergarten or higher educational level. There are several areas where students working in groups excel compared to students working independently, such as; thinking capabilities, course satisfaction, knowledge development, and social/communication skills (Barkley et al., 2014). For the past four decades, such learning is described by the myriad of the term; however, this group-based process is commonly known as collaborative working. Group-based learning is built on developmental and educational theory and involves constructing knowledge socially (Slavich \& Zimbardo, 2012).

In an educational setting, collaborative learning is an instructional method that allows students to learn by helping each other. This learning demands working in small heterogeneous groups through student group interaction, which enhances individual learning (Riley \& Anderson, 2006). According to Johnson and Johnson (2008), students maximize their own and other's learning by working together to promote socialization and learning among the students. The techniques and principles offering students to work effectively are rendered by collaborative learning (Jacobs et al., 2016). Further, collaborative learning facilitates student-centered pedagogy as the teacher's role changes to a facilitator from deliverer because students start acquiring knowledge on their own and create meanings. Similarly, Doymus (2008) stated that students are likely to accomplish their shared goals by working together through collaborative learning, also known as an instructional technique. Collaborative learning also plays a vital role in the classroom environment as it encourages communication and support among peers (Norman, 2005).

The terms including collaborative, group learning, and cooperative learning can be used interchangeably to minimize cooperative individual learning through student engagement. The diversity among students is used to establish equal participation, mutual engagement, and social interaction among peers. In a previous study by Woolfolk-Hoy (2005), group learning differs from collaborative learning because, in group work, students are divided into groups, and a specific task is assigned to them. On the contrary, Macpherson (2015) stated that collaborative learning's scope is extended beyond simple group learning and assigning specific duties. Cooperation among students is the primary requirement of students, as they depend on each other for performing the classroom tasks. 
The language instructors use various active learning strategies for years to promote participation and interaction among the students. Collaborative learning is among those active learning strategies that increase communication, motivation, and collaboration. However, collaborative learning seems frustrating for the students and teachers if it is not implemented carefully. Previous studies have focused on highlighting the effectiveness of collaborative learning compared to traditional learning strategies (Erdem, 2009; Mahmoud, 2014) and the benefits of using collaborative learning for students (Othman \& Murad, 2015). These studies have focused on evaluating techniques used for implementing collaborative learning and its impact on students' attitudes. Few previous studies have also shown significant improvement of collaborative learning on the development of motivation, positive attitude, self-autonomy, and interaction among the students (Saleh, 2012; Mahmoud, 2014).

Moreover, other studies showed the benefit and challenges associated with the implementation of collaborative learning while considering the urgent need to provide training about implementing collaborative learning among Saudi teachers (Alfares, 2017; Almula, 2017; Raja et al., 2017). Therefore, the present study contributes to the literature. It aims to assess collaborative learning's role in enhancing oral interaction among the students when implemented in English as a Foreign Language (EFL) classrooms by language teachers.

The study is likely to clarify the positive role of collaborative learning in Saudi English classrooms by the EFL teachers. The study results would help the teachers guide them about the utilization of collaborative learning in improving communication and interaction among the students. It will draw teachers' attention towards the challenges encountered by the students after applying the technique of collaborative learning in teaching practices. This in turn would help them to meet the students' needs by recognizing the factors affecting the implementation of collaborative learning. The study would also provide suggestions to the stakeholders to improve teachers and students and the practical implementation of collaborative learning.

\section{Theoretical Background}

There is a significant influence of different approaches and theories, including constructivism, humanistic approach, and second language acquisition theories, on the collaborative learning concept's theoretical foundation (Stepanovienè, 2013). In the humanistic approach, collaborative learning mainly focuses on a supportive learning environment and student autonomy during the learning process. Students are likely to listen to each other, cooperate, support, and manage diversity to face difficulties in the learning process as they work together. It is believed that this approach increases motivation and reduces stress and fear. Similarly, learning is perceived as a social process through people's interactions rather than an individual strategy based on sociocultural theory. According to Dewey (1938), students are likely to construct meaning and knowledge through peer interactions and gain personal experiences in a supportive environment. Interaction with others also offers social expertise, language, knowledge, values, morality, and rules (Piaget, 1964). A recent study by Almula (2017) showed that collaborative learning offers students expertise and ideas to achieve their goals. A positive learning environment is fostered through social interaction resulting in more extraordinary achievement among the students. The application of collaborative learning in Karshen's second language acquisition theory indicates the significance of improved language acquisition that provides opportunities to the learners for communicating and negotiating meanings in a social context (Richard, 2005). A collaborative learning environment offers excellent opportunities for the student learners to ask questions, discuss issues, defend opinions, exchange ideas, and clarify concepts. This environment plays a vital role in facilitating language learning by maximizing the oral interaction among students and enabling a high degree of comprehensible input. It is also possible to apply the principles of communicative learning in collaborative learning. Social interaction and communication among the students are mainly emphasized by communicative language learning and collaborative learning, which further help establish a close relationship with peers.

Previous studies have confirmed the significance of incorporating collaborative learning in teaching. For instance, Jacobs et al. (2016) explained the benefits of collaborative learning in increasing motivation, improving students' attitudes towards learning, improving students' achievements, their collaboration skills, and rendering more significant opportunities to the teachers for assessing student learning. Another study by Alhabeedi (2015) stated that motivation, participation, and a sense of responsibility among students are promoted in the collaborative learning environment. Students' learning and academic success are supported by collaborative learning as it keeps valuable information in mind for a longer time. Moreover, it improves communication skills, enhances self-respect, helps express ideas during the discussion, develops social skills, and enhances meta-cognitive thinking skills (Erdem, 2009).

Further, Koutselini (2008) stated that a wide range of experiences like enhancing communication skills (social 
skills and high-order thinking skills) and active learning opportunities are provided by collaborative learning. A collaborative learning environment renders positive outcomes for students' academic achievements; instead, it is beneficial for building social interaction and students' psychological health. In a competitive classroom, students develop friendly relation through collaborative learning, which leads to an increase in student motivation and decreases stress. The use of collaborative learning in understanding conflict management and the development of appropriate interpersonal skills helps promote inter-group associations among students belonging to different ethical and cultural backgrounds. It prepares students for acquiring and developing generic skills such as analytic and cognitive skills, teamwork skills, and collaborative skills (Natoli et al., 2014).

To differentiate between collaboration and cooperation, Yang et al. (2005) stated that collaboration focuses on working together; whereas, cooperation means working together. Similarly, the group work technique provides a comfortable and secure environment to the students with no anxiety (Ruiz, 2014). There is a significant impact of collaboration and cooperation on students' willingness to interact using the target language (Alhebaishi, 2019). Similarly, the positive attitude of students towards learning second language (English) is promoted during collaborative learning as promotion of interaction improved the vocabulary of those students (Gömleksiz, 2007). The positive attitude of university students towards collaborative learning was revealed by Nausheen et al. (2013), which was highlighted in the form of enjoyment, peer support, satisfaction, and better understanding. Another study by Burke (2011) showed that students' motivation to get better grades enhances in the collaborative learning environment. Previous studies have also shown that most students prefer collaborative learning for better understanding and participation in classroom activities.

\section{Material and Methods}

The study included participants from 10th grade, aged between 14 and 15 years, from an anonymous school in Saudi Arabia. Collaborative learning was implemented in the classrooms of selected students for 12 weeks by the English teachers. A total of 10 participant students were selected randomly from the cooperative learning classes, and survey interviews were conducted. The students were asked about their experiences in the new collaborative learning environment to learn English. The information about students' perceptions in a collaborated learning environment was gathered using interview protocol designed by Gillies and Boyle (2011) and further modified by the researcher. The semi-structured interviews comprised of 8 questions. The instrument after adaptation was validated through triangulation, which adds depth to the collected data. This step is extremely important in case of qualitative researches using multiple data collection techniques for finding the meaning that the study participants want to frame. The use of the triangulation method in this study helped the researcher to understand different endeavors. There is high chance of biases considering the cultural and experimental background of the researcher that can affect the results' interpretations.

Opportunities for elaboration are provided to the students in semi-structured interviews. The interviews were conducted in Arabic because it was their mother tongue, allowing better expression of ideas, unlike English. The interview with each student lasted for 30-40 minutes that were audiotaped. Later, the audio was fully transcribed by the researcher's cultural and experimental background approach was used in this study to present and analyze the interview data, which involves the transcription and coding of themes emerging from the obtained data. To ensure that the themes represented the interview data, the researcher reviewed the entire data carefully. The students' keywords and phrases in responding to different questions helped the researcher identify the themes. Strauss and Corbin (1998) used the procedure for conducting qualitative analysis by making themes was followed. For instance, the researcher broke the phrases, examined, compared, and categorized them for better understanding. This resulted in the emergence of four themes as follows; impact of academic achievements, social skills and self-confidence, and better oral interaction through collaborative learning.

\section{Results and Discussion}

The thoughts and experiences of students' learning the English language in a collaborative environment were identified through the interview. The data about perceptions of EFL learners about the efficacy of collaborative learning was grouped in different themes as follows.

\subsection{Impact on Academic Achievements}

Impact on academic achievement is the first theme from data in the collaborative learning environment. Some of the students perceived that the collaborative learning environment helped them learn effectively, and they were delighted with their academic achievements. The students had started working in groups after the implementation of collaborative learning in the English classroom. The majority of the students expressed their satisfaction with collaborative learning as it enhanced English outcomes in speaking skills. According to one of the students; 
"My understanding of English lessons has increased through collaborative learning, and my English has improved too" (Student 4)

Another student added that;

"I am now able to communicate much better with my teacher in English" (Student 9)

One of the students expressed his views by stating that;

"I have observed significant improvement in my English grammar skills as I write sentences in English or communicate in English" (Student 8)

One of the previous studies by Lord (2001) also showed that students are likely to achieve higher grades and achieve desired goals by participating in collaborative learning classrooms compared to the traditional learning method.

Some students voiced that working in groups positively impacted their motivation level and tendency to use English communication skills. Considering this, one of the students commented that;

"Learning English in a collaborative environment has motivated me to learn the most difficult skill of conversing in English" (Student 5)

Further, another student commented that:

"Initially, I hated studying English, but after the implementation of collaborative learning, I have started enjoying during this class as it encourages me" (Student 7)

These statements agree with one of the previous studies conducted by Shaaban (2006), stating that collaborative learning classrooms offer students to identify the value of studying a second language which motivates and encourages them to achieve excellence. One of the students revealed that;

"In our daily routine, the teacher just used to speak, and we listened. But now, the collaborative learning environment has offered to work in groups, which is a good solution to avoid boredom" (Student 2)

One of the students pointed out that:

"I am happy with this new environment as it motivates me to learn. Previously, I did not like the way teachers used to lecture us" (Student 5)

The students showed that they acquired a wide range of academic skills by learning in a collaborative environment. According to one of the students;

"I have noticed that my English-speaking skills have gone better, and I can communicate with my peers without facing many difficulties" (Student 5)

One of the other students remarked that;

"Collaborative learning method taught us to listen to others, which is very important" (Student 2)

These comments were second by Alghamdy (2019), as the results depicted that the underdeveloped interpersonal skills of students improved after introducing the collaborative learning method. A strong tendency is present among the students as they continue learning English skills in groups. Another study by Johnson and Johnson (2004) further stated that students are likely to achieve high grades if taught the collaborative teaching approach.

\subsection{Social Skills and Self-confidence}

The collaborative learning environment is likely to increase social skills and self-confidence among the students. This was confirmed in the interview with the students as they stated that there is a significant improvement in their social skills after studying in a collaborative environment. One of the students said that;

"I now have enough confidence to talk with my teachers, my classmates, and public too. I was not able to talk freely before" (Student 10)

Another student commented that:

"Previously, it was tough for me to present even a simple topic in front of people; however, now I feel comfortable to talk in front of people, and I believe this confidence I have learned through collaborative learning" (Student 3)

The students were very excited about presenting different topics in front of the whole class with confidence. One of the students narrated that:

"I got a chance to present topic, and this is an unforgettable event for me. I am very happy with this 
collaborative learning environment" (Student 1)

A previous study by Kao (2003) showed that the use of the collaborative learning method improved students' speaking skills and enabled them to present in front of other students. In the present study, the students declared confident enough to perform different tasks with confidence as collaborative learning has improved their self-confidence and social skills. In a similar context, one of the students expressed that:

"At present, I can manage different job and even lead a team, which was nearly impossible for me to do before" (Student 4)

The students also declared that the collaborative learning environment had taught them responsibility, oral presentation, and respect for different opinions. This is also highlighted by one of the previous studies stating that the collaborative learning approach prepares students for enhancing their social skills and increase practical cooperation with their peers (Gillies, 2003; Alghamdy, 2019).

\subsection{Better Oral Interaction Through Collaborative Learning}

The majority of the students stated that they could learn faster and easier through collaborative learning techniques, unlike the traditional learning techniques. The students' significant difference was in their speaking and interacting skills with their teachers and peers. A collaborative learning environment offers the students a level playing, rather than positioning the teacher as the center of knowledge and responsibility to convey the complex concepts to the students. One of the students stated that:

"After experiencing collaborative learning environment, I would prefer it only because we get to learn a lot through this. Learning English through individual learning is not at all suited for shy students" (Student 10)

A similar study clearly stated that the introduction of collaborative learning and improvement in interpersonal skills are positively correlated (Vo, 2010). Students believed that the collaborative learning method increases student motivation to communicate easily with their peers and teachers in English, unlike the individual learning strategy. Successful teamwork depends on the synchronization of their actions towards achieving a common goal. This results in positive interdependence among the students. One of the students narrated that:

"I have started loving my English class through collaborative learning. I have started conversing in English with my peers too" (Student 7)

One of the students also remarked that:

"Individual learning was just tedious; however, no positive outcome was seen as I am observing after learning in a collaborative environment" (Student 3)

Like the present study, Gillies (2003) demonstrated that cooperative working offers more verbal assistance than the learners who are not working in cooperative groups. One of the students stated that:

"I have learned a lot from my classmates, and this all is only because of collaborative learning environment" (Student 6)

\section{Conclusion}

The present study has focused on identifying the oral interaction among students in the collaborative learning environment. The analysis depicted that most students believed that collaborative learning improved their social interaction, communication with peers, improved oral presentation skills, respecting different opinions, performing various roles, building self-confidence, and increasing motivation. Overall, the study showed noticeable progress in oral and verbal interaction in the EFL classroom after the implementation of collaborative learning techniques.

In the light of the positive impact of collaborative learning as perceived by the students, the study suggests that collaborative learning concepts should be implemented for in-service and pre-service teachers in EFL education programs. There is also a need to restructure the education programs by integrating field experiences, extending student teaching, and developing a collaborative relationship with the teachers. Teachers need to act as researchers in a collaborative learning environment rather than just deliverers of syllabus or technicians. In this way, their teaching methods would reflect the curriculum goals and contribute to the curriculum's renewal. Students are motivated to show patience by the EFL teachers for training them and improving their language use. Lastly, the study suggests that enough time is required by the syllabus designers for collaboration supplemented with a wide range of activities to practice group work.

\section{References}

Alfares, N. (2017). Benefits and Difficulties of Learning in Group Work in EFL Classes in Saudi Arabia. English 
Language Teaching, 10(7), 247-256. https://doi.org/10.5539/elt.v10n7p247

Alghamdy, R. Z. (2019). EFL learners' reflections on cooperative learning: Issues of implementation. Theory and Practice in Language Studies, 9(3), 271-277. https://doi.org/10.17507/tpls.0903.03

Alhabeedi, E. (2015). Increasing students' participation by using cooperative learning in library and research courses (Master's thesis, The University of New York at Fredonia).

Alhebaishi, S. M. (2019). Investigation of Cooperative Learning Techniques and Attitudes in Language Learning Classrooms. International Journal of Applied Linguistics and English Literature, 8(2), 219-230. https://doi.org/10.7575/aiac.ijalel.v.8n.2p.219

Almulla, M. (2017). An Investigation of Cooperative Learning in a Saudi High School: A Case Study on Teachers' and Students' Perceptions and Classroom Practices (Doctoral dissertation, University of Leicester). https://doi.org/10.20319/pijss.2016.s21.715737

Barkley, E. F., Cross, K. P., \& Major, C. H. (2014). Collaborative learning techniques: A handbook for college faculty. John Wiley \& Sons.

Burke, A. (2011). Group work: How to use groups effectively. Journal of Effective Teaching, 11(2), 87-95.

Dewey, J. (1986, September). Experience and education. In The Educational Forum (Vol. 50, No. 3, pp. 241-252). Taylor \& Francis Group. https://doi.org/10.1080/00131728609335764

Doymus, K. (2008). Teaching chemical bonding through jigsaw cooperative learning. Research in Science \& Technological Education, 26(1), 47-57. https://doi.org/10.1080/02635140701847470

Erdem, A. (2009). Pre-service teachers' attitudes towards cooperative learning in mathematics course. Procedia-Social and Behavioral Sciences, 1(1), 1668-1672. https://doi.org/10.1016/j.sbspro.2009.01.295

Gillies, R. M. (2003). Structuring cooperative group work in classrooms. International Journal of Educational Research, 39(1-2), 35-49. https://doi.org/10.1016/s0883-0355(03)00072-7

Gillies, R. M., \& Boyle, M. (2011). Teachers' reflections of cooperative learning (CL): A two-year follow-up. Teaching Education, 22(1), 63-78. https://doi.org/10.1080/10476210.2010.538045

Gömleksiz, M. N. (2007). Effectiveness of cooperative learning (jigsaw II) method in teaching English as a foreign language to engineering students (Case of Firat University, Turkey). European journal of engineering education, 32(5), 613-625. https://doi.org/10.1080/03043790701433343

Jacobs, G., Power, M., \& Loh. (2016). The teacher's sourcebook for cooperative learning: Practical techniques, basic principles, and frequently asked questions. Skyhorse Publishing: New York.

Johnson, D. W., \& Johnson, R. T. (2004). Implementing the" Teaching Students To Be Peacemakers Program." Theory into Practice, 43(1), 68-79. https://doi.org/10.1207/s15430421tip4301_9

Johnson, D. W., \& Johnson, R. T. (2008). Social interdependence theory and cooperative learning: The teacher's role. In The teacher's role in implementing cooperative learning in the classroom (pp. 9-37). Springer, Boston, MA. https://doi.org/10.1007/978-0-387-70892-8_1

Kao, E. S. (2003). The effectiveness of small-group discussion on the improvement of EFL learners' reading ability in large. Taipei, Taiwan: Tamkang University Press.

Koutselini, M. (2008). Teacher misconceptions and understanding of cooperative learning: An intervention study. The Journal of Classroom Interaction, 43(2), 34-44.

Lord, T. R. (2001). 101 reasons for using cooperative learning in biology teaching. The American Biology Teacher, 63(1), 30-38. https://doi.org/10.2307/4451027

Macpherson, A. (2015). Cooperative Learning group activities for college courses. Surrey, BC Canada: Kwantlen Polytechnic University.

Mahmoud, M. M. A. (2014). The effectiveness of using the cooperative language learning approach to enhance EFL writing skills among Saudi university students. Journal of Language Teaching and Research, 5(3), 616. https://doi.org/10.4304/jltr.5.3.616-625

Natoli, R., Jackling, B., \& Seelanatha, L. (2014). The impact of instructor's group management strategies on students' attitudes to group work and generic skill development. Pedagogies: An International Journal, 9(2), 116-132. https://doi.org/10.1080/1554480X.2014.912519

Nausheen, M., Alvi, E., Munir, S., \& Anwar, R. (2013). Attitudes of postgraduate students towards cooperative 
learning. Journal of Educational Research (1027-9776), 16(2), 107-115.

Norman, D. G. (2005). Using STAD in an EFL elementary school classroom in South Korea: Effects on student achievement, motivation, and attitudes toward cooperative learning. Asian EFL Journal, 35(3), 419-454.

Othman, H. G., \& Murad, I. H. (2015). A STUDY ON KURDISH STUDENTS'ATTITUDES TO GROUP WORK IN THE EFL CLASSROOM. European Scientific Journal, 11(11).

Piaget, J. (1964). Development and learning. In R. E. Ripple \& V. N. Rockcastle (Eds.), Piaget rediscovered: A report of the conference on cognitive studies and curriculum development (pp. 7-20). Ithaca, NY: Cornell University.

Raja, M. S. H., Qureshi, A. S. A. R., \& Albesher, K. B. (2017). Application of cooperative learning strategies (CLS) for students' focused teaching (SFT) in EFL class: An experimental study in the summer remedial course for adult learners. Journal of Language Teaching and Research, 8(2), 237-252. https://doi.org/10.17507/jltr.0802.05

Richards, J. (2005). Communicative language teaching today. Cambridge University Press: New York.

Riley, W., \& Anderson, P. (2006). Randomized study on the impact of cooperative learning: Distance education in public health. Quarterly Review of Distance Education, 7(2), 129.

Ruiz, C. (2014). The use of group work activities to foster EFL oral production and reduce anxiety in intermediate students. A paper submitted to the School of Human Sciences in Partial Fulfillment of the degree of BA in English and French. The University of Narino.

Saleh, M. I. (2012). The Effectiveness of Cooperative Learning on EFL Proficiency: A Case Study of Grade Ten Female Classroom in the New Developed High School Project in Riyadh, Saudi Arabia (Doctoral dissertation, Department of English at the College of Arts, King Saud University).

Shaaban, K. (2006). An initial study of the effects of cooperative learning on reading comprehension, vocabulary acquisition, and motivation to read. Reading Psychology, 27(5), 377-403. https://doi.org/10.1080/02702710600846613

Slavich, G. M., \& Zimbardo, P. G. (2012). Transformational teaching: Theoretical underpinnings, basic principles, and core methods. Educational psychology review, 24(4), 569-608. https://doi.org/10.1007/s10648-012-9199-6

Stepanovienè, A. (2013). Cooperative learning in the context of foreign language teaching and learning. Scientific Articles, 9, 246-254.

Strauss, A., \& Corbin, J. (1998). Basics of qualitative research techniques. Thousand Oaks, CA: Sage publications.

Vo, T. K. A. (2010). Is cooperative learning a suitable teaching and learning method in Vietnam. Journal of Science and Technology, 6(41), 207-210.

Woolfolk-Hoy, A. E. (2005). Educational Psychology. Active Learning Edition.

Yang, A., Chan, A., Lik-ko Ho, L., \& Tam, B. (2005). Does an open forum promote learning among students? A collaborative learning approach. Asian EFL Journal, 7(3), 1-11.

\section{Copyrights}

Copyright for this article is retained by the author(s), with first publication rights granted to the journal.

This is an open-access article distributed under the terms and conditions of the Creative Commons Attribution license (http://creativecommons.org/licenses/by/4.0/). 